\title{
Análisis general del brote epidemiológico causado por los virus Zika y chikunguña en Colombia
}

\author{
Nelson Giovanny Rincón Silva ${ }^{\text {- Dorian Armando Acevedo Castro }}{ }^{\mathbf{b}}$
}

\begin{abstract}
Resumen: Los virus son agentes infecciosos, causantes de diversas enfermedades en los seres humanos, comportamiento demostrado, por ejemplo, con el brote de viruela en los nativos americanos que causó la muerte de miles de ellos en la época de la Conquista. En los últimos años, se ha reportado la reaparición de algunos padecimientos causados por virus en países tropicales, que amenazan con convertirse en pandemias. Padecimientos como las fiebres del Zika y el chikunguña han afectado a varios países de América del Sur, principalmente, Brasil, Perú y Colombia, donde se reportaron miles de contagios y algunos casos de desenlace fatal. Debido a la importancia del tema, se realizó una revisión crítica para evidenciar las características de los virus, las manifestaciones clínicas del contagio, estadísticas de los afectados y los tratamientos disponibles. Asimismo, se analizaron las acciones preventivas propuestas por la oms y el Instituto Nacional de Salud (INH). Finalmente, se consultaron algunas propuestas en el desarrollo de vacunas, de donde se concluye que, a pesar de los significativos avances y cuantiosas posibilidades en fases clínicas, aún no hay ningún producto comercial para ninguno de los dos virus analizados, pero se proyecta tenerlos después de 2020.
\end{abstract}

Palabras clave: virus; virus del Zika; virus del chikunguña; trastorno hemorrágico; fiebre; epidemia; infección; vacuna

Fecha de recepción: 12 de agosto de 2018 Fecha de aprobación: 28 de julio de 2019

Cómo citar: Rincon Silva NG, Acevedo Castro DA. Análisis general del brote epidemiológico causado por los virus Zika y chikunguña en Colombia. Revista Med 27(2): 49-64. Disponible en: https://revistas.unimilitar. edu.co/index.php/rmed/article/view/3606

a Licenciado en Química, Especialista en Química Biológica de la Universidad de las Islas Baleares, Magíster en Ciencias Químicas, Departamento de Química. Universidad de las Islas Baleares. Mallorca, España. Correo electrónico: giovannyrincons@gmail.com

b Magíster en Ciencias Químicas, Doctor (c) en Ciencias Químicas, Universidad de los Andes, Bogotá D.C, Colombia. 


\title{
General Analysis of the Epidemiological Outbreak Caused by the Zika and Chikungunya Viruses in Colombia
}

\begin{abstract}
Viruses are infectious agents causing various diseases in humans; this behavior is demonstrated by, for example, the outbreak of smallpox in Native Americans that resulted in the death of thousands at the time of the Conquest. In recent years, the reappearance of some diseases caused by viruses has been reported in tropical countries, which threaten to become pandemics. Conditions such as Zika and chikungunya fevers have affected several countries in South America, mainly Brazil, Peru, and Colombia, where thousands of infections and some fatal outcomes were reported. Due to the importance of the matter, the characteristics of the viruses, clinical manifestations of the infection, statistics on those affected, and treatments available are critically reviewed. Likewise, the preventive actions proposed by the WHO and the National Institute of Health (NIH) are discussed. Finally, some proposals in the development of vaccines are checked to conclude that, despite the significant advances and considerable possibilities in clinical phases, there is still no commercial products for either of the two viruses analyzed, but they are planned for after 2020
\end{abstract}

Keywords: Virus; Zika virus; chikungunya virus; bleeding disorder; fever; epidemic; infection; vaccine

\section{Análise geral do surto epidemiológico causado pelos vírus Zika e Chikungunya na Colômbia}

Resumo: Os vírus são agentes infecciosos que causam várias doenças nos seres humanos, esse comportamento pode ser demonstrado, por exemplo, com o surto de varíola que causou a morte de milhares de nativos americanos na época da conquista. Nos últimos anos, o reaparecimento de algumas doenças causadas por vírus tem sido relatado em países tropicais, emergindo a ameaça delas se tornarem pandemias. Doenças como a febre zika e a febre Chikungunya afetaram vários países da América do Sul, principalmente o Brasil, o Peru e a Colômbia, onde milhares de infecções e alguns casos de resultados fatais foram relatados. Devido à importância desse tema, realizamos uma revisão crítica para mostrar as características dos vírus, as manifestações clínicas da infecção, as estatísticas sobre os afetados e os tratamentos disponíveis. Além disso, as ações preventivas propostas pela Organização Mundial da Saúde (OMS) e pelo Instituto Nacional de Saúde (INH) também foram analisadas. Finalmente, a partir da consulta de algumas propostas no desenvolvimento de vacinas, concluímos que, apesar dos avanços significativos e das possibilidades consideráveis nas fases clínicas, ainda não existe nenhum produto comercial para enfrentar os vírus analisados neste estudo. Porém, depois de 2020, é provável que algum produto seja disponibilizado no mercado.

Palavras-chave: vírus; vírus Zika; vírus Chikungunya; complicação hemorrágica; febre; epidemia; infecção; vacina 


\section{Introducción}

Desde la época antigua el ser humano ha padecido diversas enfermedades causadas por agentes infecciosos microscópicos llamados virus, es decir "toxina" o "veneno" $(1,2)$. Los virus son básicamente una cápside proteica con su material genético dentro de ella; son demasiado pequeños para ser percibidos por los microscopios convencionales y no pueden reproducirse por sí mismos, por lo que necesitan de una célula para su replicación. Pueden infectar animales, vegetales, hongos o bacterias $(3,4)$.

A lo largo de las últimas décadas, algunas enfermedades crónicas padecidas por la humanidad son generadas por virus, por ejemplo, el síndrome de inmunodeficiencia adquirido (sida), enfermedad en la cual el sistema de defensa es atacado por el virus de inmunodeficiencia humana (VIH), además de la hepatitis y la rabia, ente otras. Estas patologías, además, son de gran importancia por sus graves consecuencias sociales, psicológicas y económicas a nivel mundial $(5,6)$.

Otras enfermedades causadas por los virus son las fiebres hemorrágicas, un grupo de enfermedades causadas por cuatro familias de virus, entre las que se encuentran los virus del Ébola y el Marburg; el virus de la fiebre de Lassa y el virus de la fiebre amarilla (7-9). Algunas de estas fiebres hemorrágicas causan síntomas leves, pero otras, como las causadas por los virus Ébola y Marburg, causan complicaciones graves en la salud e incluso pueden causar la muerte (8-10).

En los últimos años, el aumento de contagios por algunos virus específicos ha captado la atención de varios centros de salud y grupos de investigación del mundo, particularmente, en América. Entre los principales virus que han causado estos recientes episodios se encuentran los virus del Ébola, el Zika y el chikunguña $(11,12)$. Por ejemplo, el último y más importante brote de Ébola se presentó en África Occidental en 2014, donde se registraron más de 1000 defunciones; en 2019, se presentaron algunos casos en Europa y en el primer semestre de 2019 se han reportado algunos brotes en el Congo, por lo que se mantiene la alerta mundial. Respecto al virus chikunguña (vCHIK), llegó desde África a América a finales de 2013 $(10,11)$. De igual manera, al virus del Zika (ZIKv), también proveniente del África, llegó entre 2015 y 2016 al continente americano y su incidencia alcanzó niveles pandémicos (10-12).

A partir de este contexto, en este documento se presenta una revisión de los padecimientos producidos por los contagios por ZIKV y VCHIK en la población de América del Sur y, centralmente, en Colombia. Asimismo, se realiza una contextualización general de los virus estudiados, la presentación de algunas estadísticas en el periodo del brote y alcance de sus efectos en la población Colombiana, así como las características más importantes de aquellos virus.

\section{Metodología}

Para la investigación, se sig uió una metodología general que abarca los siguientes pasos: (a) definición del tema, (b) elaboración de un plan de trabajo, (c) búsqueda bibliográfica, (d) análisis y selección de los documentos, (e) enriquecimiento de la documentación mediante discusión y conceso de los autores, (f) análisis de los documentos, (g) síntesis de la información y $(\mathrm{h})$ redacción del artículo de revisión.

Para la búsqueda bibliográfica, se utilizaron varias fuentes documentales. Se realizó una búsqueda bibliográfica en junio de 2018, en los buscadores especializados: Sciencedirect, Nature Publishing Group, Pubmed, Scopus y NCBI, entre otros; y se consultaron artículos relevantes del tema de las últimas dos décadas. Así como diversas publicaciones científicas de Argentina, Colombia y Brasil. Asimismo, se analizaron los reportes de prensa más representativos de índole nacional e internacional, dado que estos medios de comunicación son las principales fuentes de información de la población. Los registros obtenidos oscilaron entre 150 y 200, tras la combinación de las diferentes palabras clave. En general, se revisaron 88 publicaciones de artículos científicos y de prensa, así como comunicaciones y carteles oficiales de la Organización Mundial de la Salud (oMs). También, se analizaron algunos estudios recientes, publicados por grupos de investigación de estados Unidos y 
Europa en microbiología clínica. Finalmente, para la edición de los archivos PDB e imágenes se emplearon los programas Maestro, Schrödinger, LLC, New York, NY, 2018 y Chimera 1.13.1, 2019.

El análisis de los documentos llevó a cabo de acuerdo con las siguientes etapas: inicialmente, las fuentes se clasificaron con base en su contenido y se evaluaron, las secciones de resumen y conclusiones de cada artículo (primera evaluación). Posteriormente, se seleccionó y extrajo la información más relevante o sobresaliente, con la finalidad de retirar la irrelevante y reducir el volumen del material de análisis. La etapa final de esta fase fue verificar los datos en extractos individuales (segunda evaluación). La síntesis del documento se basó, nuevamente, en una serie de subetapas: se ordenó y combinó la información extraída dentro de cada epígrafe; luego, se realizó una evaluación comparativa de los diferentes extractos o datos (tercera evaluación). Acto seguido, se condensó la información en una estructura y forma más accesible y de acuerdo con los objetivos y las fuentes. Por último, se llevó a cabo la escritura del documento.

Es importante mencionar que las revisiones bibliográficas de este tipo presentan algunas limitaciones y sesgos, por la forma como se construyen. Un limitante principal es la pérdida de información generalizada, debida principalmente a dos factores: la búsqueda bibliográfica y a la selección de documentos. En el primer caso, es posible que no se haya considerado información relevante en diferentes artículos, debido a que dichos artículos contienen información valiosa para la revisión pero que no se consideró, por estar publicada en revistas no incluidas en las bases de datos consultadas. El segundo factor que limita los trabajos de este tipo es la selección de documentos, que se debe principalmente a la formación de los autores, ya que esto, naturalmente, dará el enfoque general del trabajo. Este aspecto, además de limitar el trabajo, es también responsable de las limitaciones y sesgos en este tipo de trabajos.

Con respecto al sesgo en este tipo de trabajos, es necesario considerar que en el proceso existe un criterio subjetivo ineludible. Por ello, como se mencionó, los documentos se seleccionaron considerando las secciones de resumen y conclusiones.
En este punto, debido a la formación en ciencia (bioquímica) de los autores, es inevitable que un mayor enfoque hacia la información que involucre datos y características más cercanos a esta ciencia. Esto podría haberse traducido en que se hubiera dejado de lado el tema netamente médico, al menos un poco. Lo anterior puede plantearse como un aspecto no necesariamente negativo, pero es necesario tener en cuenta que la información recopilada puede analizarse desde diferentes consideraciones, dependiendo de quien realice el análisis.

\section{Análisis y discusión}

\section{Epidemiología y análisis histórico de los virus}

Dentro de la clasificación de los virus, los del grupo Arbovirus (del inglés arthropod-borne viruses, es decir virus llevados por artrópodos) son trasmitidos por artrópodos, principalmente, mosquitos. Estos virus afectan diferentes zonas del mundo, especialmente, las ubicadas en zonas tropicales. Además, estos virus han llamado la atención recientemente, debido al incremento en el número de consultas médicas, generado a causa de diversas afecciones en salud en pobladores de países de América del Sur como Brasil, Colombia, Perú, Ecuador y Venezuela, con síntomas similares a los producidos por la infección con el virus del dengue (13-15). En la actualidad, se sabe con seguridad que tales afecciones son producidas por los virus ZIKV y VCHIK. El primero produce una fiebre denominada fiebre del Zika, enfermedad del Zika o, simplemente, zika; mientras el segundo produce una enfermedad que recibe el nombre de artritis epidémica chikunguña o fiebre de chikunguña $(16,17)$.

El zIKv es un virus emergente de la familia flaviviridae, una familia de virus que se propagan principalmente por vectores artrópodos, especialmente garrapatas y mosquitos (18). Estos virus contienen un genoma ARN monocatenario de carácter positivo, por lo que se incluyen en el Grupo Iv de la Clasificación de Baltimore. El genoma no es segmentado, es decir, es lineal, con una extensión de 9,6 a 12,3 kilobases. Las partículas virales son esféricas, con un diámetro aproximado de 40-60 nm y presentan 
una envoltura vírica (Figura 1a), donde se aprecia la terminal 5' que presentan un cap del nucleótido metilato (Figura 1b). Entre las principales enfermedades infecciosas producidas por esta familia viral se incluyen: encefalitis, dengue, meningoencefalitis, fiebre amarilla y hepatitis C (18).

a. Estructura general de los flavivirus y su envoltura

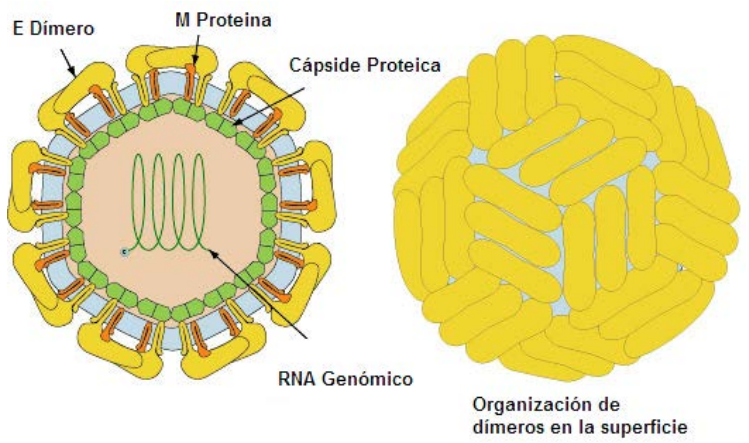

b. Organización del genoma del flavivirus y procesamiento poliproteico

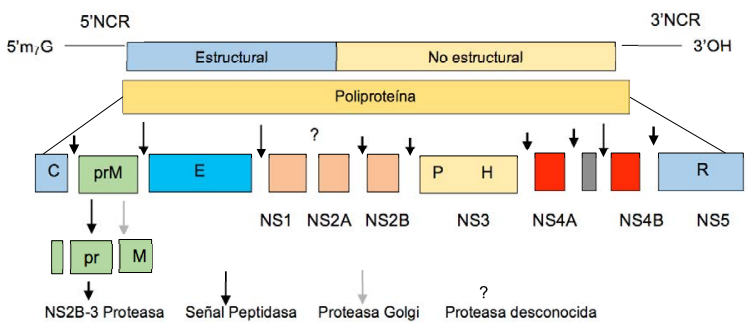

El virion RNA es del alrededor de 11 kb de tamaño; en la parte superior, el genoma viral con las regiones proteicas codificantes estructurales y no estructurales y el 5'- y 3'-NCRS (regiones no codificantes, los recuadros siguientes indican las proteínas virales generadas por el procesamiento proteólico en cascada, las letras P, H y R indican la localización de la proteasa NS3, la helicasa NS3 RNA, y el RdRp (RNA-dependiente RNA polimerasa) NS5, respectivamente.

Figura 1. Estructura, organización del genoma y procesamiento poliproteico de los flavivirus.

Fuente: tomado y editado por autores de Zhang et al. Nat Struct Biol. 2003; 10(11):907-12.

Por su parte, el zIKv (Figura 2), trasmitido principalmente por el mosquito Aedes aegypti (19, 20-22), fue aislado por primera vez en 1947, en Uganda, desde especies de monos macacos Rhesus, durante un estudio de fiebre amarilla en el bosque tropical de Zika (ecosistema ubicado en Entebbe a 23 kilómetros de Kampala, capital de Uganda); es un lugar con exuberante vegetación que alberga todo tipo de animales y plantas, entre ellos, cuarenta especies de mosquitos $(23,24)$.

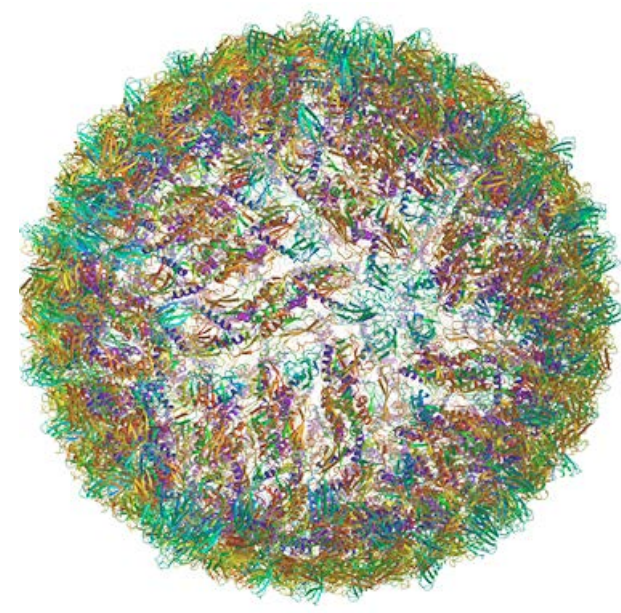

Figura 2. Cryo-EM. Estructura del virus del Zika [ZIKV]. Fuente: tomado de Protein Data Bank y Kostyuchenko et al. Nature. 2016; 533(7603):425-8. (22-23).

En 1948, el virus fue aislado de un grupo de mosquitos de la familia Aedes africanus, presentes en la misma región del bosque (25). Posteriormente en Nigeria, entre 1968 y 1975, el virus fue aislado y reportado en seres humanos, cuando pudo comprobarse que los individuos que habitaban esta región presentaban anticuerpos específicos para este virus. Después de aislar el virus en Nigeria, subsecuentemente, se realizaron más aislamientos de cepas del virus en mosquitos de Aedes spp., en bosques cercanos al bosque Zika, situados en África y Malasia (24-26).

En 1977, el científico investigador Olson reportó siete personas en Indonesia, con la infección del Zika durante un estudio serológico. Después, se realizaron estudios serológicos que evidenciaron infecciones de Zika en pacientes humanos, en Egipto, Nigeria, Uganda, India, Malasia, Indonesia, Pakistán, Tailandia, el norte de Vietnam y Filipinas. Ello demostró que, para 1980, el virus ya presentaba una amplia ocurrencia alrededor del mundo $(26,27)$.

En abril de 2007, en el estado de Yap, Estados Federados de Micronesia, Oceanía, se detectó una epidemia de fiebre y erupción cutánea asociada presumiblemente con el virus del dengue (DENV), por lo que se llevaron muestras de pacientes afectados en esta epidemia al Laboratorio de Diagnóstico de Arbovirus, en los Centros para el Control y la Prevención de Enfermedades (CDC, Fort Collins, 
EE. UU.). Después de hacer los estudios serológicos pertinentes, se confirmó que la infección en el estado de Yap fue generada por el virus Zika y no por el virus del dengue, como se pensaba inicialmente (28-31). Este reporte demostró la primera evidencia del virus Zika fuera de África y Asia. Después de la notificación de los primeros reportes del virus, se han presentado otros brotes de Zika en islas del Océano Pacífico, desde 2007 (29-31).

Durante 2014, el virus se introdujo en la Isla de Pascua, Chile, y, a comienzos de 2015, el ministerio de salud de Brasil y el instituto Evandro Chagas confirmaron dieciséis casos positivos en Brasil (2729). A finales de 2015, en Brasil se estimó entre 0,4 y 1,3 millones de casos de infección del virus, lo que lo hace el país más afectado de América del Sur por este virus (27-30). En marzo de 2016, el virus se había extendido activamente por lo menos a 33 países, principalmente, en América y también a África y Oceanía (21). Después, la expansión del virus continuó hacia América Central y la totalidad de América del Sur.

En cuanto al virus chikunguña, la sintomatología que lo acompaña fue descrita, por primera, vez en 1779. Entonces, fue caracterizado como una variante del virus del dengue, pero fue solo hasta inicios del siglo veinte, cuando fue reconocido como un virus diferente (32). Los brotes de chikunguña se reportaron por primera vez a mediados de 1952, en Tanzania, África, desde donde se dispersó hacia el continente asiático, luego a Europa y, posteriormente, al continente americano. A pesar de todo, el lugar exacto de origen del virus es incierto $(33,34)$.

Dada la rápida dispersión del virus y la ausencia de un tratamiento efectivo contra él, el chikunguña ha adoptado un carácter de importancia médica mundial $(34,35)$. El vchik (Figura 3) fue reconocido rápidamente como un virus diferente, puesto que su principal síntoma consiste en un fuerte dolor de articulaciones, de ahí su nombre, derivado de un término del idioma macondo (un idioma bantú del sur de Tanzania y norte de Mozambique), que se refiere a los procesos de "secarse", "encorvarse" o "retorcerse" $(34,35)$.

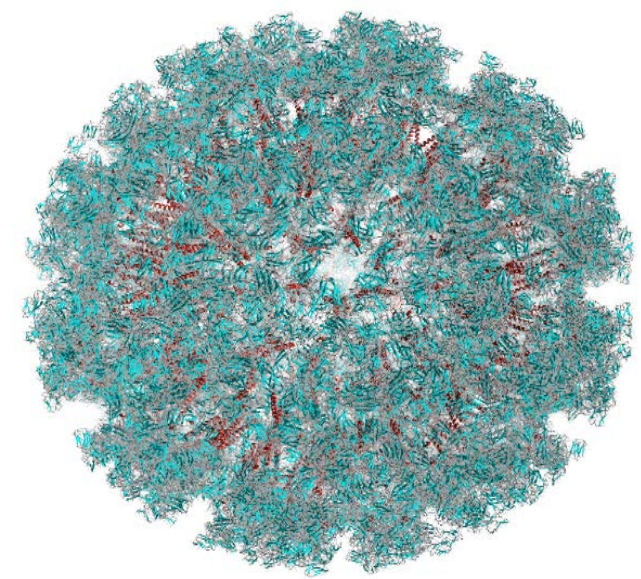

Figura 3. Estructura del virus Chikunguña.

Fuente: tomado Protein Data Bank y Sun et al. Elife. 2013; 2:e00435. $(35,36)$.

Una vez identificado el virus y parte de su ciclo de vida, fue posible reconocer sus primeros brotes fuera del continente africano (37-40). Durante el periodo de 1960-1980, se presentaron fuertes brotes de la epidemia en países asiáticos, principalmente en Camboya e India (39-41). Hasta el momento, estudios filogenéticos han demostrado que durante los primeros años de la epidemia (1958-1973), el vсHIK proveniente de África había mutado para formar una nueva cepa (42-44). Tanto la cepa africana como la asiática permanecieron restringidas a estos dos continentes hasta 2004, cuando se presentaron brotes en islas del Índico, que permitieron la dispersión posterior del virus al contiene americano $(45,16)$.

Recientemente, se han desarrollado algunos estudios para determinar la causa por la cual el virus amplió su rango de infección. Entre los resultados, se determinó una mutación presente en la glicoproteína E1 del virus, en la cual, el aminoácido codificante 226 (círculo verde de la Figura 4a) cambió su posición (46-47), ya que la glicoproteína E1 es la que permite la infección de las células del mosquito. El cambio de aminoácidos ALA por VAL en esta proteína permitió la infección de un nuevo vector (en este caso, una nueva especie de mosquito). Así, el moquito Aedes albopictus se convirtió en el principal vector del chikunguña en zonas tropicales y templadas, debido a su capacidad de tolerar cambios bruscos de temperatura (44-46). 
a. La figura roja muestra el nuevo lugar de inserción del aminoácido 226 en la cápside de E1 (47)

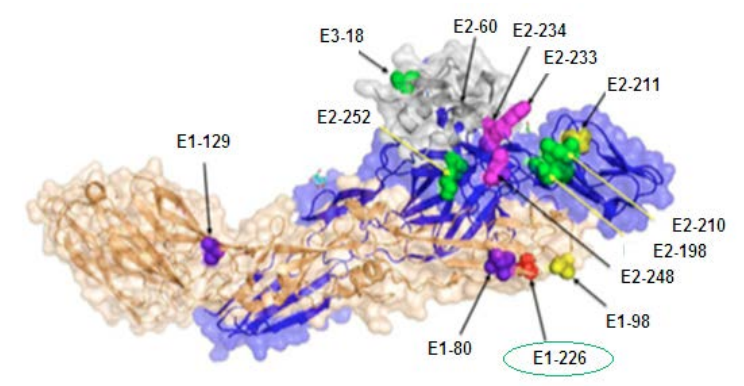

b. Estructura secundaria del virus VCHIK

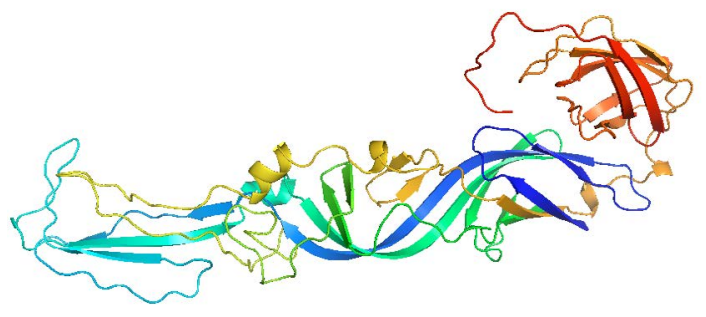

Figura 4. Glicoproteína E1 del virus del chikunguña. Fuente: tomada y adaptada de Protein Data Bank y Fox et al. Cell. 2015; 163(5):1095-107. (47,48).

Este cambio estructural de la proteína determinó la dispersión del virus a nivel global (44-47). En la actualidad, el chikunguña representa una problemática que va más allá del sistema de salud público, debido a la ausencia de un tratamiento eficiente para el virus, lo que ha llevado a los centros asistenciales a almacenar medicamentos únicamente para el tratamiento de los síntomas, acciones insuficientes durante un brote (49-51).

Por otro lado, se considera que los países americanos son más vulnerables a brotes continuos de la epidemia, debido a que aún no se ha generado un sistema inmune grupal, es decir, las personas son más fáciles de vulnerar por la infección, puesto que aún no han desarrollado acciones inmunes resistentes al virus, contrario a lo que ya sucede, por ejemplo, en el continente africano (49-51).

\section{Manifestaciones clínicas de las fiebres del Zika y el chikunguña}

En general, los síntomas de la fiebre del Zika constituyen aumentos considerables en la temperatura corporal, dolores articulares crónicos, cefaleas, debilidad general y dolor muscular (26). En el inicio la enfermedad, la infección aparece relativamente leve, limitada y no es letal; además no presenta síntomas en el $80 \%$ de los casos. Pero, en algunos casos, los síntomas inician entre 2 y 7 días después de la picadura del mosquito, cuando ya se evidencia dolor de cabeza, conjuntivitis, dolor de estómago, mareos y fiebre; a los cuales siguen las complicaciones más importantes: malestar general, anorexia, eflorescencia o erupciones maculopapulares y un pronunciado dolor articular $(28,29,51)$.

El verdadero potencial de la enfermedad es aún desconocido, sin embargo, durante la pasada epidemia en Polinesia Francesa, se reportaron cerca de 73 casos del síndrome de Guillain-Barré y otros padecimientos neurológicos. Se sospecha que estos síntomas son complicaciones de la infección, pero esta relación aún se encuentra en investigación $(28,52)$.

Actualmente, la preocupación más importante en el cuadro clínico de esta infección es debido a que se presume el virus zIKV está asociado con el aumento de la incidencia de microcefalia en neonatos de mujeres que hayan contraído el virus durante el embarazo. En esta afección, la cabeza de los niños es más pequeña, comparada con la de otros de su misma edad y sexo (Figura 5), lo que puede afectar el desarrollo de las funciones motrices y del habla, además de implicar hiperactividad y retraso mental, en numerosas ocasiones $(26,53,54)$.
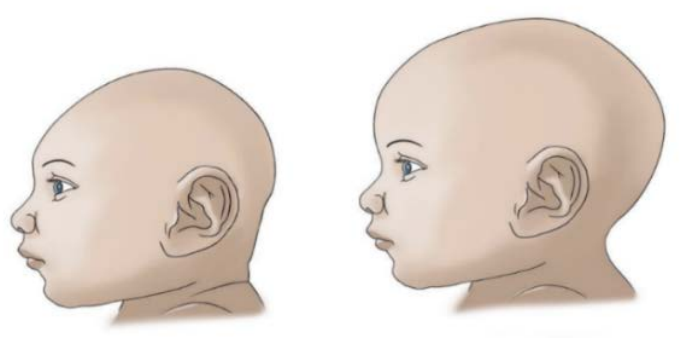

Figura 5. Ilustración de malformación física producida por la microcefalia.

Fuente: Autores. 
La sintomatología de la fiebre chikunguña se caracteriza por la aparición inmediata de fiebre, a veces de más de $40{ }^{\circ} \mathrm{C}$. A esta fiebre le sigue un eritema, acompañado de dolores articulares. Otros signos frecuentes son los dolores musculares y de cabeza, las náuseas, el cansancio y erupciones cutáneas. El virus puede causar una enfermedad aguda, subaguda o crónica. El período de incubación del virus de chikunguña varía entre uno y doce días. La infección puede ser asintomática, pero, por lo general, entre $75 \%$ y $95 \%$ de los infectados desarrollan síntomas. Otros síntomas reportados en pacientes han sido fatiga, rash (eflorescencia), problemas digestivos y conjuntivitis $(32,33,55-58)$.

Durante la reciente epidemia de 2015, se observó que la fiebre de chikunguña se manifiesta en varias fases. Dentro de la fase aguda, se identificaron dos etapas: una viral, durante los primeros 5-7 días, seguida de una etapa de convalecencia de aproximadamente 10 días, en los cuales los síntomas empeoran, pero el virus aún no puede detectarse en la sangre (56-59). Luego, se manifiesta la fiebre con inicio de la viremia, cuando el nivel de virus vCHIK en la sangre se correlaciona con la intensidad de los síntomas. Cuando la inmunoglobulina $\mathrm{m}$ y los anticuerpos aparecen en la sangre, la viremia empieza a disminuir, pero el dolor de cabeza, insomnio y cansancio extremo se manifiestan. Seguido de la fiebre, se presenta un fuerte dolor de articulaciones y rigidez que puede persistir semanas o incluso meses. Aquel dolor puede ser debilitante y a menudo resulta casi en la inmovilidad total de las articulaciones afectadas. Se presenta en más de una articulación, en la mayoría de los casos, y puede ocurrir en el 87-98\% de los afectados (55-60).

Las articulaciones más afectadas son las de brazos y piernas. El dolor se produce con mayor frecuencia en articulaciones periféricas, como las muñecas, tobillos, así como en otras articulaciones mayores como hombros, codos y rodillas. El dolor también puede presentarse en músculos y ligamentos $(59,61)$. La mayoría de los pacientes se recupera completamente, pero en algunos casos los dolores articulares pueden durar meses o años.

Adicionalmente, se han descrito casos ocasionales con complicaciones oculares, neurológicas y cardíacas y también con molestias gastrointestinales. Las complicaciones graves no son frecuentes, pero, en personas mayores, la enfermedad puede conllevar a la muerte.

A menudo los pacientes solo tienen síntomas leves y la infección puede pasar inadvertida o diagnosticarse erróneamente como dengue, particularmente, en zonas donde este último es frecuente. Asimismo, las personas con enfermedades como presión arterial alta, diabetes o enfermedades del corazón presentan mayor riesgo y complicaciones $(56,60)$.

La causa de pacientes con síntomas crónicos prolongados en el tiempo aún no tiene una justificación exacta, ya que los resultados para las pruebas autoinmunes o reumatoides resultan negativos en ellos $(33,56,60)$. En estos pacientes, el antígeno vírico se ha podido encontrar en biopsias musculares en personas infectadas, luego de varios meses de contagio; adicionalmente, el antígeno viral y el virus se han encontrado en macrófagos de la articulación sinovial, en personas que han experimentado episodios de recaídas hasta 18 meses después de la infección, por lo que puede inferirse que el virus conlleva a infecciones persistentes en humanos $(34,36,52-58)$.

\section{Organismos causantes de la trasmisión y expansión de los virus}

Ha sido posible identificar que tanto la fiebre del Zika como la del chikunguña son trasmitidas por picaduras de mosquitos, específicamente del género Aedes (38). Este género de mosquitos culícidos (culicidae: familia de dípteros nematóceros conocidos coloquialmente como mosquitos) es frecuente en todo el mundo y, especialmente, en áreas tropicales y subtropicales, con condiciones geográficas particulares, como suelos inundables con grandes reservorios de aguas estancadas (3840). El nombre procede de aquel género proviene del griego aēdēs, es decir, "odioso". Transmiten, diversas enfermedades, como la fiebre amarilla, el dengue y la dirofilariasis, entre otras $(42,43)$. Además, en Polinesia, el Aedes polynesiensis trasmite la filariasis linfática, producida por Brugia y otros nemátodos $(47,48,50)$.

Los mosquitos Aedes, usualmente, exhiben bandas negras y blancas en cuerpo y patas, pero 
también pueden presentar otras coloraciones. Algunos científicos sostienen que parte de las especies debieran trasladarse al género Stegomyia, al haber elevado este subgénero al rango de género, pero aún se reconoce con su clasificación clásica (46). El género Aedes incluye varios subgéneros, como Aegypti, Aedimorphus, Fredwardsius y Stegomyia (48-50).

En el ser humano, la infección surge como resultado de las picaduras por mosquitos hembra infectados al succionar la sangre de otras personas infectadas (40-42). El virus infecta el intestino medio del mosquito y luego se extiende hasta las glándulas salivales, en un período de 8-12 días. Tras este período de incubación, el mosquito puede transmitir el virus a las personas, al picarlas con fines exploratorios, defensivos o alimentarios. Los mosquitos suelen picar durante toda la mañana e inicios de la tarde y actuar tanto en el interior como afuera de las viviendas $(50,52,61)$.

De acuerdo con la oms, este insecto utiliza como criadero espacios pequeños que pueden naturales o artificiales. Depositan sus huevos en recipientes que contienen agua que, en un par de días, se convierten en larvas, las cuales crecen hasta convertirse en zancudos adultos. Por eso, se aconseja suprimir posibles criaderos en agua estancada en viviendas o cerca de ellas; adicionalmente, se recomienda utilizar insecticidas y repelentes sobre la piel y la ropa $(52,60-62)$.

Se ha determinado que el mosquito puede picar a las personas sin ser percibido, porque se acerca silenciosamente y pica, principalmente, en codos y tobillos. Este comportamiento se concluyó de acuerdo con una investigación del Centro para el Control y la Prevención de Enfermedades (CDC) de Estados Unidos. Por último, usualmente, los mosquitos prefieren picar a los humanos, aunque en ocasiones también atacan a diferentes animales domésticos, principalmente, a los perros (60-62).

En lo que respecta a la trasmisión del virus ZIKV, además de la mencionada picadura del mosquito y la transmisión sexual, se han observado formas alternativas de transmisión, entre las que se destacan las transmisiones por transfusiones y trasplantes, así como la transmisión congénita y durante el parto (64-66).

\section{Diagnóstico de los virus en los humanos}

El primer aspecto que debe considerarse para llevar a cabo el diagnóstico es preguntar a la persona posiblemente infectada si ha visitado áreas donde se haya reportado transmisión dentro de los últimos 15 días previos al inicio de los síntomas $(46,51)$. En el laboratorio, el diagnóstico del virus del Zika se realiza durante la etapa aguda de la enfermedad, por medio de un equipo de reacción en cadena de la polimerasa con transcriptasa inversa (RT-PCR, por sus siglas en inglés), empleando muestras de suero (62-67). Sin embargo, el virus también puede ser detectado en muestras de orina y saliva. Para las muestras de suero se emplea detección molecular (RT-PCR); estas deben ser tomadas dentro de los primeros 6 días después de iniciada la sintomatología.

La detección de inmunoglobulina IgM mediante la técnica ELISA para el virus ZIKV debe realizarse en muestras de suero tomadas a partir del cuarto día de evidencia de síntomas $(29,38,41)$. Los resultados positivos de las muestras requieren ser confirmados mediante la prueba de neutralización en cultivos celulares bajo agarosa. Esta última sólo puede ser realizada en laboratorios especializados que trabajan con cultivos celulares. En esta prueba, se requieren dos muestras: una obtenida el cuarto día y otra obtenida 15 días después de la primera. En términos generales los resultados de infecciones por flavivirus pueden ser de análisis complejo, ya que pueden presentarse cruces serológicos de otros virus, como el del dengue $(53-56,63,64)$.

Por su parte, el diagnóstico del chikunguña es similar al del virus del Zika: se emplean diversos criterios analíticos realizados en laboratorio y se basa en la detección directa o indirecta del virus con alguna de las siguientes pruebas: aislamiento viral, detección de RNA viral por medio de la técnica de RT-PCR, detección de anticuerpos IgM en muestra de suero, recolectada durante la fase aguda o subaguda, por medio de la técnica ELISA (51-53). 


\section{Brote epidemiológico y situación actual de los virus}

El virus del Zika ha afectado gravemente algunas poblaciones de Colombia $(67,68)$. Hasta junio de 2016, se habían reportado cerca de casos 50000 de infectados por el virus, de los cuales 9000 fueron mujeres embarazadas, según informes del Instituto Nacional de Salud [INs] $(65,66)$. La presencia del virus se mantenía en 282 municipios del país, hacia finales de 2016, y la mayoría de afectados eran mujeres $(67,4 \%)$, con mayor incidencia en personas entre los 25 y 29 años [14,1\%] (75,76).

Según reportes de 2016, a partir del ingreso a la fase endémica, desde la semana epidemiológica 29 hasta la semana epidemiológica 37 de 2016 (mediados de septiembre), fueron notificados cerca de 3020 casos de enfermedad por virus Zika; los cuales, sumados con los que se notificaron hasta el cierre de la fase epidémica en la semana epidemiológica 28 de 2016, sumaron un total de 8826 casos confirmados y 95129 sospechosos; de estos, 91383 proceden de 507 municipios donde se confirmaron casos por laboratorio y 3746, de 283 municipios donde no se habían confirmado casos hasta esa fecha.

En la semana epidemiológica 37 de 2016, se registraron 405 casos, 99 de esa semana y 306 de semanas epidemiológicas anteriores, notificados de manera tardía. Se reportaron 405 casos sospechosos (de municipios con y sin casos confirmados por laboratorio); sumando los casos confirmados y sospechosos, los departamentos que concentraron cerca del $60,0 \%$ del total de los casos notificados fueron Valle del Cauca, Norte de Santander, Santander, Tolima y Huila (68-73).

Asimismo, en Colombia, el Ministerio de Salud vinculó al ZIKV como responsable de la muerte de 3 enfermos de Guillain-Barré (69). Además, se reportaron más de 800000 infectados por el virus en 2016, y medio millar de casos de microcefalia, similares a los casos de Brasil, país más afectado con más de un millón y medio de casos (68-73). Se cree que el virus se expandirá por todo el continente americano, en Perú, Ecuador y Venezuela, exceptuando Canadá y Chile, según declaraciones de la oms (73-76).
Con respecto al vCHIK, el INs indicaba alrededor de 60 muertes causadas por el virus en Colombia entre 2014 y 2015 (68-73,76-78). Además se reportó que la tasa de letalidad corresponde a $0,014 \%$, ya que un total de 450000 personas padecieron la enfermedad durante este periodo $(71,73)$. El Ins informó, además, que el mayor número de muertes por este virus se dio en Norte de Santander (12 casos), seguido por el Tolima (9 casos), mismo número registrado en Cundinamarca $(71,73)$. De acuerdo con el organismo especializado, seis de los fallecidos estuvieron aquejados simultáneamente con dengue (73). Además, se resaltó la importancia de que el personal de salud no deje de inspeccionar el dengue, aún en la presencia de chikunguña, dada su importancia en morbilidad y mortalidad.

\section{Vacunas contra los virus Zika y chikunguña}

Existen vacunas eficaces contra diversos Flavivirus, por ejemplo, contra los virus que producen la fiebre amarilla o la encefalitis (la japonesa y la transmitida por garrapatas). Estas vacunas fueron desarrollas hacia 1930. Por su parte, el dengue también cuenta con una vacuna, desarrollada recientemente en 2016, denominada engvaxia, fármaco que es producido por la farmacéutica francesa Sanofi Pasteur.

Sin embargo, no existe todavía una vacuna comercial efectiva contra los virus del Zika y chikunguña; no obstante, diversos estudios arrojan resultados prometedores, según afirma el doctor Anthony Fauci, director del Instituto Nacional de Alergia y Enfermedades Infecciosas de Estados Unidos. La demora para su obtención se debe a que el proceso para desarrollar una vacuna certificada y llevarla a producción es aún bastante complejo, dado que realizar los estudios en animales, realizar ensayos clínicos y obtener la licencia de aplicación comercial en humanos tarda de 10 a 12 años, por lo menos.

A pesar de lo anterior, algunos centros de investigación aseguran haber obtenido una vacuna efectiva contra el vchiK, como el grupo de investigación de la University of Texas Medical Branch (EE. UU.), en convenio con universidades de Brasil, que ha experimentado con animales y que, en la última etapa de sus investigaciones, ha realizado 
pruebas en humanos con buenos resultados contra este virus: la vacuna probada generó una adecuada respuesta inmune en los 25 voluntarios que participaron en las pruebas, sin que sufrir efectos secundarios graves $(78,80)$. La molécula experimental utilizada es una "vacuna recombinante de virus vivo atenuado", creada a través de la modificación genética del vchik. La cepa en la cual se desarrolló la vacuna es diferente, comparada con el virus natural, en dos aspectos: por un lado, no puede causar la enfermedad $y$, por otro, tampoco infecta a los mosquitos transmisores, característica importante para asegurar que la vacuna no inicie una nueva transmisión en zonas que presentan casos reportados $(53,78,80)$. En cambio, genera una respuesta inmune para proteger contra futuras infecciones.

Asimismo, en México también especialistas del centro de investigaciones regionales Hyedo Noguchi de la Universidad Autónoma de Yucatán están llevando a cabo estudios para encontrar una vacuna efectiva contra este virus (77). Asimismo, el Consejo Superior de Investigaciones Científicas (CSIC) de España afirmó haber desarrollado una vacuna contra el virus del chikunguña, transmitido por el mosquito tigre, es decir, el Aedes albopictus $(80,81)$. De forma paralela, en el Centro de Biotecnología del csic también se ha desarrollado un prototipo de vacuna probado con éxito en animales (ratones y monos) y que protege frente a la infección. Este último producto está preparado para avanzar ahora hacia los ensayos clínicos en seres humanos (78,80-81).

En cuanto a la vacuna para prevenir la fiebre del Zika, el Instituto Nacional de la Salud (NIH, por sus siglas en inglés) de Estados Unidos afirmó, en marzo de 2016, que la vacuna podría estar lista en septiembre de ese mismo año, sin embargo, esto no sucedió debido a la complejidad del virus $(82,84)$. Se ha reportado que próximamente va a tenerse lista una vacuna para probarla en humanos, pero aún sin disponibilidad para distribución y comercialización (83). La vacuna desarrolla por el NIH es la que se encuentra en etapas más avanzadas y que cuenta con mayor efectividad en comparación con otras que están desarrollándose, según reportes científicos.
Sin embargo, hay otras vacunas con resultados prometedores como la desarrollada por Sanofi, quien anunció que en la primavera de 2017 empezaron ensayos preclínicos de un producto farmacéutico, en el que estaba involucrado cerca de un centenar de investigadores. A pesar de ello, en aquella fase sólo se llevaron a cabo pruebas en animales, pero ya estaban proyectando pruebas también en humanos $(82,84)$.

Otras dos vacunas en proceso de desarrollo son la de la compañía de india Bharat Biotech, con sede en Hyderabad, y la de la farmacéutica estadounidense Inovio. El investigador Fauci ha afirmado que el producto que ellos han desarrollado estaría enfocado para aplicarse en mujeres embarazadas, debido al vínculo con los casos de microcefalia y síndrome de Guillain-Barré asociados al Zika, como asegura la oms. Por ello, la producción de esta vacuna para este público específico involucraría un proceso más complejo, teniendo en cuenta los riesgos para el feto $(82,84)$. El doctor Fauci ha afirmado que, si los resultados de los estudios de la fase I de la vacuna son efectivos, podría inferirse que la vacuna estaría lista para ser distribuida en los próximos años (2020).

Al respecto, es de anotar que es de vital importancia desarrollar la vacuna en este plazo, ya que se ha comprobado ampliamente la relación de la infección con el desarrollo de microcefalia, además de posibles daños cognitivos (82-86). Es este aspecto, en efecto, se tienen resultados de un estudio mediante análisis de células madre humanas, en el que se ha comprobado que el virus de Zika infecta selectivamente células pertenecientes a la corteza cerebral, las hace más propensas a morir y les reduce su capacidad de reproducción $(82,84)$.

\section{Prevención contra la infección de los virus}

A nivel general, donde hay presencia de los mosquitos vectores de estos virus, se recomienda a la comunidad usar mosquiteras en las ventanas mientras se duerme, para evitar la entrada de los insectos y, con ello, prevenir el contagio de los virus mediante picaduras $(79,81,82)$. Asimismo, es aconsejable no mantener las ventanas abiertas, 
además de eliminar el agua estancada, como en los jardines, dado que el mosquito vive y se reproduce en esos ambientes $(53,78,80)$. También es aconsejable que las personas vistan ropa blanca o muy clara, con manga larga, siempre que se pueda y usar repelente de insectos $(73,81)$.

Debido a la falta de tratamiento y una vacuna efectiva contra los virus, es necesario frenar su expansión, erradicando la presencia del mosquito transmisor. Un método para lograrlo es evitar que el insecto se reproduzca o hacer que muera antes de que llegue a transmitir la enfermedad (86). Para ello, pueden emplearse mosquitos genéticamente modificados (sistema que aún está evaluándose, pero que la oms ha respaldado ampliamente), puesto que el virus se ha expandido por todo el continente americano y se cree que puede afectar a alrededor de cinco millones de personas (86-88).

\section{Conclusión}

Es indispensable conocer de forma adecuada las diferencias entre las fiebres producidas por los virus del dengue, Zika y chikunguña, debido a que presentan sintomatología similar que puede causar confusión, en cuanto a prevención y tratamiento en las zonas más afectadas. Por tanto, es necesario desarrollar una prueba diferencial rápida y oportuna para identificar el virus causante de la fiebre y empezar el tratamiento lo antes posible. Asimismo, es necesario atacar la reproducción de los mosquitos portadores de estos virus y tomar en cuenta todos los protocolos de seguridad establecidos por la oms y el ins.

Actualmente, se ha dado por superado el pico epidémico del virus Zika, registrado en Colombia durante el año 2015 e inicios de 2016. Sin embargo, en algunas regiones del territorio del país, sigue presentándose circulación activa del virus y departamentos como Meta, Quindío y Valle del Cauca siguen en la etapa de transmisión activa. En cuanto al chikunguña, en Colombia y América del Sur, el brote ya se detuvo, pero es importante no disminuir las precauciones en el control de los brotes de este virus.
Se reconoce que además de las picaduras de mosquitos, el virus Zika puede propagarse con la transmisión por vía sexual, por transfusiones de sangre, trasplantes, transmisión congénita y durante el parto. Esto torna más complejo prevenirlo y tratarlo, sumado al hecho de que el virus está asociado con el aumento de la incidencia de microcefalia, lo que lo hace más peligroso para las poblaciones donde se han presentado brotes. Por ello, es sumamente necesario su control, eliminación y erradicación definitiva.

Aunque existen vacunas efectivas contra muchos Flavivirus, actualmente, no se cuenta con una vacuna eficaz contra los virus del chikunguña y el Zika. Sin embargo, recientemente, se han logrado grandes avances; además, hay varios grupos de investigación y farmacéuticas de diferentes países buscando tratamientos y vacunas efectivas para ambos virus. Algunos de estos afirman que podría contarse con una vacuna efectiva hacia 2020.

Finalmente, es de gran importancia, continuar las investigaciones para ampliar el conocimiento sobre el comportamiento y las características biológicas de los virus y lograr el desarrollo efectivo de vacunas y tratamientos, a fin de evitar su propagación.

\section{Agradecimientos}

Los Autores expresan un especial agradecimiento al grupo Computational Bio-Organic Chemistry (сово), perteneciente a la Universidad de los Andes, por facilitar la consulta del material bibliográfico de la temática analizada y por facilitar el uso del software empleado en la modificación de imágenes y archivos.

\section{Conflicto de intereses}

Los autores declaran no tener ningún tipo de conflicto de intereses.

\section{Fuente de financiación}

La elaboración del artículo fue autofinanciada. 


\section{Referencias}

1. Díaz FJ, Estrada S, Franco L, Jaramillo JM, Maestre AE, Ospina S, Robledo C, Robledo J. Microbiología de las infecciones humanas. Bogotá: Corporación para investigaciones biológicas; 2007.

2. Vargas M. Virología médica. Bogotá: Editorial Universidad Nacional; 2002.

3. Peñaranda J. Biología molecular de virus. Bogotá: Editorial universidad Nacional; 1996.

4. Cabello R. Microbiología y parasitología médica. Editorial medica panamericana: Cuidad de México; 2007.

5. Gao F, Balles E, Robertson D, Chen Y, Rodenburg C, Michael S, Cummins L, Arthur L, Peeters M, Shaw G, Sharp P. Origin of HIV-1 in the chimpanzee Pan troglodytes. Nature. 1999; 397(6817): 436-41.

6. Delgado RA. El agente etiológico que produce que produce el sida. In: ASERCOMI SL (ed.). Sida, un problema de todos. Perspectivas para el próximo milenio. Madrid: ASERCOMI SL; 1998.

7. MedlinePlus. Hemorrhagic Fevers: Also called: VHFs [Internet]. 2016 [actualizado en septiembre de 2019; consultado el 20 de noviembre de 2019]. Disponible en https://medlineplus.gov/hemorrhagicfevers.html

8. Jordan MC, Jordan GW, Stevens JG, Miller G. Latent herpesviruses of humans. Annals of Internal Medicine. 1984; 100(6):866-80.

9. Tan DX, Reiter RJ, Manchester LC. Ebola virus disease: Potential use of melatonin as a treatment. Journal of pineal research. 2014; 57(4): 381-4.

10. Hampton T. Vaccines against Ebola and Marburg viruses show promise in primates studies. Medical news and perspectives. JAMA. 2005; 294(2):01-15.

11. Rivera García O. Aedes aegypti, virus dengue, chinkugunia, zika y el cambio climático. Máxima alerta médica y oficial. Revista Electrónica de Veterinaria. 2014; 10(15):01-10.

12. Besnard M, Eyrolle-Guignot D, Guillemette-Artur P, Lastere S, Bost-Bezeaud F, Marcelis L et al. Congenital cerebral malformations and dysfunction in fetuses and newborns following the 2013 to 2014 Zika virus epidemic in French Polynesia. Euro Surveill. 2016; 21(13): 01-09.

13. Center for Disease Control and Prevention (CDC). Arbovirus Catalog [Internet]. Atlanta (EE. UU: CDC. [Consultado julio de 2018]. Disponible en https:// wwwn.cdc.gov/arbocat/

14. OPS/OMS. Dengue en las Américas [Internet]. [Consultado julio de 2018]. Disponible en http://www.bvsde.paho.org/bvsasv/e/fulltext/denguel/denguel.html
15. Avilés G, Rangeon G, Baroni P. Epidemia por virus dengue-2 en Salta, Argentina, 1998. Medicina (B Aires). 2000; 60(6):875-9.

16. McCrae AW, Henderson BE, Kirya BG, Sempala SD. Chikungunya virus in the Entebbe area of Uganda: isolations and epidemiology. Trans R Soc Trop Med Hyg. 1971; 65(2):152-68.

17. Fauci A, Morens DM. Zika virus in the Americas - Yet another arbovirus threat. Perspectives. N Engl J Med. 2016; 374:601-4.

18. Romero MR, Serrano MA, Vallejo M, Efferth T, Alvarez M, Marin JJ. Antiviral effect of artemisinin from Artemisia annua against a model member of the Flaviviridae family, the bovine viral diarrhoea virus (BVDV). Planta médica. 2006;72(13):1169-74.

19. Zhang W, Chipman PR, Corver J, Johnson PR, Zhang Y, Mukhopadhyay S, Baker TS, Strauss JH, Rossmann MG, Kuhn RJ. Visualization of membrane proteindomains by cryo-electron microscopy of dengue virus. Nat Struct Biol. 2003; 10(11):907-12.

20. Musso D, Gubler DJ. Zika Virus. Didier Musso, Duane J. Gubler. Zika virus. Clin Microbiol Rev. 2016; 29:487524.

21. Sampathkumar P, Sanchez J. Zika Virus in the Americas: A review for clinicians. Mayo Clinic Proceedings. Elsevier Ltd. 2016; 91(4): 514-21.

22. Protein Data Bank (PDB). The cryo-EM structure of Zika Virus [Internet]. [Consultado diciembre de 2017]. Disponible en http://www.rcsb.org/pdb/ngl/ngl.do?p$\mathrm{dbid}=5$ IRE $\&$ bionumber $=1$

23. Kostyuchenko VA, Lim EX, Zhang S, Fibriansah G, Thiam-Seng N, Justin SG, Ooi JS, Lok SM. Structure of the thermally stable Zika virus. Nature. 2016; 533(1):425-8.

24. Mattar S, González M. Now is the time for the Zika virus. Revista MVZ Córdoba. 2015; 20(2):4511-2.

25. Duffy MR. Zika virus outbreak on Yap Island, federated states of Micronesia. New England Journal of Medicine. 2009; 360(24):2536-43.

26. Dick GW. Zika virus (I). Isolations and serological specificity. Transactions of the Royal Society of Tropical Medicine and Hygiene. 1952; 46(5): 509-20.

27. Marchette NJ. Garcia R, Rudnick A. Isolation of Zika virus from Aedes aegypti mosquitoes in Malaysia. American Journal of Tropical Medicine and Hygiene. 1969; 18(3): 411-5.

28. Laerte Pinto JV, Luz K, Parreira R, Ferrinao P. Zika virus: A review to clinicians. Acta Med Port. 2015; 28:760-5. 
29. Olson J, Ksiazek T, Suhandiman G, Triwibowo V. Zika virus, a cause of fever in Central Java, Indonesia. Transactions of the Royal Society of Tropical Medicine and Hygiene. 1981; 75(3):389-93.

30. Ramírez MC. Epidemia por el virus del zika: un reto para los sistemas de salud de las Americas. Boletín del Instituto Nacional de Salud. 2016; 22:1-3.

31. Lanciotti R, Kosoy O, Laven J, Velez J, Lambert A, Johnson A, Stanfield S, Duffy M. Genetic and serologic properties of Zika virus associated with an epidemic, Yap State, Micronesia, 2007. Emerg Infect Dis. 2008; 14(8):1232-9.

32. Carey DE. Chikungunya and dengue: a case of mistaken identity? J. Hist. Med. Allied Sci. 1971; 26:24362.

33. Powers AM, Logue CH. Changing patterns of chikungunya virus: re-emergence of a zoonotic arbovirus. Journal of General Virology. 2007; 88(9):2363-77.

34. Ng LC. Hapuarachchi HC. Tracing the path of Chikungunya virus - Evolution and adaptation. Infection, Genetics and Evolution. 2010; 10(7): 876-85.

35. Protein Data Bank (PDB). Electron cryo-microscopy of Chikungunya virus [Internet]. [Consultado el 4 diciembre de 2017]. Disponible en https://www.rcsb.org/ structure/3J2W

36. Sun S, Xiang Y, Akahata W, Holdaway H, Pal P, Zhang X, Diamond M, Nabel G, Rossmann M. Structural analyses at pseudo atomic resolution of Chikungunya virus and antibodies show mechanisms of neutralization. E Life. 2013; 435(12): 01-27.

37. Medical Xpress. 2014. Chikungunya virus shuts down infected cells [Internet]. [Consultado el 3 de octubre de 2017]. Disponible en http://medicalxpress.com/ news/2014-12-chikungunya-virus-infected-cells.html

38. Lee VJ, Chow A, Zheng X, Carrasco LR, Cook AR, Lye DC et al. Simple clinical and laboratory predictors of chikungunya versus dengue infections in adults. PloS Neglected Tropical Diseases. 2012; 6(9):1786.

39. Powers AM, Brault AC, Tesh RB, Weaver SC. Re-emergence of Chikungunya and Onyong-onyong viruses: evidence for distinct geographical lineages and distant evolutionary relationships. Journal of General Virology. 2000; 81(2):471-9.

40. Powell JR, Tabachnick WJ. History of domestication and spread of Aedes aegypti - A review. Memórias do Instituto Oswaldo Cruz Inst. Suppl. 2013; 108(1):11-7.

41. Coffey LL. Failloux AB. Weaver SC. Chikungunya virus-vector interactions. Viruses. 2014; 6(11):4628-63.
42. Volk SM, Chen R, Tsetsarkin KA, Adams AP, García TI, Sall AA, Nasar F, Schuh AJ, Holmes EC, Higgs S, Mahara, PD, Brault AC, Weaver SC. Genome-scale phylogenetic analyses of chikungunya virus reveal independent emergences of recent epidemics and various evolutionary rates. Journal of Virology. 2010; 84(13): 6497-504.

43. Diallo M, Thonnon J, Traore-Lamizana M, Fontenille D. Vectors of Chikungunya virus in Senegal: Current data and transmission cycles. Tropical Medicine and Hygiene. 1999; 60(2):281-6.

44. Dupont-Rouzeyrol M, Caro V, Guillaumot L, Vazeille M, D'Ortenzio E, Thiberge JM et al. Chikungunya virus and the mosquito vector Aedes aegypti in New $\mathrm{Ca}$ ledonia (South Pacific Region). Vector Borne Zoonotic Dis. 2012; 12(12):1036-41.

45. Schuffenecker I, Iteman I, Michault A, Murri S, Frangeul L, Vaney MC et al. Genome microevolution of chikungunya viruses causing the Indian Ocean outbreak. PloS Med. 2006; 3:263-73.

46. Conde M, Orjuela LI, Castellanos CA, Herrera-Varela M, Licastro S, Quiñones M. Evaluación de la sensibilidad a insecticidas en poblaciones de Aedes aegypti (Diptera: Culicidae) del departamento de Caldas, Colombia, en 2007 y 2011. Bioméicha 2015; 35(1): 43-52.

47. Fox JM, Long F, Edeling MA, Lin H, van Duijl-Richter M, Fong R, Kahle K, Smit JM, Crowe JE, Fremont DH, Rossmann M, Diamond MS. Broadly neutralizing alphavirus antibodies bind an epitope on E2 and inhibit entry and egress. Cell. 2015; 163(5):1095-107.

48. Protein Data Bank (PDB). Electron cryo-microscopy of Chikungunya virus in complex with neutralizing antibody Fab CHK265 [Internet]. [Consultado el 5 de diciembre de 2017]. Disponible en https://www.rcsb. org/structure/5any

49. Thiberville SD, Moyen N, Dupuis-Maguiraga L, Nougairede A, Gould EA, Roques P, de Lamballerie X. Chikungunya fever: Epidemiology, clinical syndrome, pathogenesis and therapy. Antiviral Research. 2013; 99(3):345-70.

50. Center for Disease Control and Prevention (CDC). Geographic distribution of chikungunya virus [Internet]. Atlanta: CDC; 2014 [consultado el 4 de octubre 2016]. Disponible en http://www.cdc.gov/chikungunya/geo/index.html

51. Leparc-Goffart I, Nougairede A, Cassadou S, Prat C, de Lamballerie X. Chikungunya in the Americas. Lancet. 2014;383(9916):514. 
52. García de Figueiredo M, Moraes Figueiredo LT. Emerging alphaviruses in the Americas: Chikungunya and Mayaro. Revista da Sociedade Brasileira de Medicina Tropical. 2014; 47(6):677-83.

53. Tovar ZM, Bolívar SA, Maestre-Serrano R. Chikungunya: aspectos generales de una enfermedad emergente en Colombia. Biociencias. 2015; 10(1):75-88.

54. Debbie-Ann T. Shirley, Nataro J. P. Zika Virus Infection. Pediatric Clinics of North America. 2017; 64(4):937-51.

55. Mlakar J, Korva M, Tul N, Popović M, Poljšak-Prijatelj M, Mraz J, Kolenc M, Resman Rus K, Vesnaver Vipotnik T. Zika virus associated with microcephaly. New England Journal of Medicine. 2016; 374(10):951-8.

56. Musso, D. Potential sexual transmission of Zika virus. Emerging infectious diseases, 2015; 21(2):359.

57. Caglioti C, Lalle E, Castilletti C, Carletti F, Capobianchi MR, Bordi L. Chikungunya virus infection: an overview. The New Microbiologica. 2013; 36(3):211-27.

58. Chevillon C, Briant L, Renaud F, Devaux C. The Chikungunya threat: An ecological and evolutionary perspective. Trends in Microbiology. 2008; 16(2):80-8.

59. Mahendradas P, Avadhani K, Shetty R. Chikungunya and the eye: A review. Journal of Ophthalmic Inflammation and Infection. 2013; 3(1):35.

60. Das T, Jaffar-Bandjee MC, Hoarau JJ, Krejbich Trotot P, Denizot M, Lee-Pat-Yuen G et al. Chikungunya fever: CNS infection and pathologies of a re-emerging arbovirus. Progress in Neurobiology. 2010; 91(2):12129.

61. Hoarau JJ, Jaffar Bandjee MC, Krejbich Trotot P, Das T, Li-Pat-Yuen G, Dassa B et al. Persistent chronic inflammation and infection by Chikungunya arthritogenic alphavirus in spite of a robust host immune response. The Journal of Immunology. 2010; 184(10):5914-27.

62. Hennessey M, Fischer M, Staples JE. Zika virus spreads to new areas - Region of the Americas, May 2015 - January 2016. American Journal of Transplantation. 2016; 16(3):1031-4.

63. Nasci RS, Wirtz RA, Brogdon WG. Protection against mosquitoes, ticks, and other arthropods. En: Brunette GW (ed.). CDC health information for international travel. New York [NY]: Oxford University Press; 2015.

64. Blasco L. Así es el mosquito Aedes aegypti, causante del Zika, el dengue y la chikungunya [Internet]. Londres: BBC. [Actualizado el 12 enero 2016; consultado el 4 de octubre de 2016]. Disponible en http://www.bbc.com/ mundo/noticias/2016/01/160112_salud_mosquito _enfermedades_zika_dengue_chikungunya_america_latina_lb
65. Tang H, Hammack C, Ogden S, Wen Z, Qian X, Li Y, Yao B, Shin J, Zhang F, Lee E, Christian K, Didier R, Jin $\mathrm{P}$, et al. Zika virus infects human cortical neural progenitors and attenuates their growth. Cell Stem Cell. 2016; 18 (5): 587-90.

66. Besnard M, Eyrolle-Guignot D, Guillemette-Artur P, Lastère S, Bost-Bezeaud F, Marcelis L, et al. Congenital cerebral malformations and dysfunction in fetuses and newborns following the 2013 to 2014 Zika virus epidemic in French Polynesia. Euro Surveill. 2016;21(13).

67. Atif M, Azeem M, Sarwar M, Bashir A, Zika virus disease: A current review of the literature. Infection. 2016; 44(6):695-705.

68. El País. Casos del virus del Zika en Colombia ya superaron los 70.000 [Internet]. [Actualizado el 24 de abril de 2016; consultado el 6 de octubre de 2016]. Disponible en http://www.elpais.com.co/elpais/colombia/noticias/casos-virus-zika-colombia-ya-superaron-70000

69. El tiempo. Publican el mayor análisis sobre zika en Colombia [Internet]. [Actualizado el 16 de junio de 2016; consultado el 5 de octubre de 2016]. Disponible en http://www.eltiempo.com/ estilo-de-vida/salud/publican-el-mayor-analisis-sobre-zika-en-colombia/16621963

70. Mareze V, Borio C, Bilen M, Fleith R, Mirazo S, Mansur D, Arbiza J, Lozano M, Bruña-Romero O. Tests in mice of a dengue vaccine candidate made of chimeric Junin virus-like particles and conserved dengue virus envelope sequences. Applied Microbiology and Biotechnology. 2016; 100(1):125-33.

71. Instituto Nacional de Salud. Dirección de Vigilancia y Análisis del Riesgo en Salud Pública 2016. Boletín epidemiológico Semanal [Internet]. [Consultado el 8 de octubre de 2016]. Disponible en http://www.ins.gov. co/boletin-epidemiologico/Paginas/default.aspx

72. Bell TM, Field EJ, Narang HK. Zika virus infection of the central nervous system of mice. Archiv fur die gesamte Virusforschung. 1971; 35(2):183-93.

73. El tiempo. Así avanza el virus en el país [Internet]. [Actualizado el 19 de marzo de 2015; consultado el 11 de octubre de 2017]. Disponible en http://www.eltiempo.com/multimedia/ especiales/chikunguna-asi-ha-crecido-la-enfermedad-en-colombia/15414235

74. El tiempo. El chikungunya entró en una fase epidémica [Internet].[Actualizadoel24demarzode2015; consultadoel3de octubrede2017]. Disponible en http://www.eltiempo.com/ colombia/cali/chikungunya-en-el-valle-del-cau$\mathrm{ca} / 15457177$ 
75. National Center for Biotechnology Information. Zika virus [Internet]. 2016 [consultado el 4 de octubre de 2016]. Disponible en https://www.ncbi.nlm.nih.gov/ Taxonomy/Browser/wwwtax.cgi

76. National Center for Biotechnology Information. Chikungunya virus. 2016 [consultado el 4 de octubre de 2017]. Disponible en https://www.ncbi.nlm.nih.gov/Taxonomy/Browser/ ww w tax.cgi? $\operatorname{mode}=$ Info \&id $=37124 \& \operatorname{lvl}=3 \& \operatorname{lin}=$ f\&keep $=1 \&$ srchmode $=1 \&$ unlock

77. Fine-Maron D. Scientific American, a Division of Nature America, Inc. The mosquito-borne disease afflicts millions and has had no approved vaccine until now [Internet]. [Consultado el 10 de octubre de 2017]. Disponible en http://www.scientificamerican.com/ article/first-dengue-fever-vaccine-gets-green-light-in3-countries/

78. El Nuevo Diario. Una vacuna contra el Chikungunya [Internet]. [Actualizado el 27 de agosto de 2015; consultado el 12 octubre de 2017]. Disponible en https://www.elnuevodiario.com. ni/nacionales/368767-vacuna-chikungunya/

79. Horwood P, Reimer L, Dagina R, Susapu M, Bande G, Katusele M, Koimbu G, Jimmy S, Ropa B, Siba P et al. Outbreak of chikungunya virus infection, Vanimo, Papua, New Guinea. Emerg Infect Dis. 2013; 19(9):1535-8.

80. La Prensa. México desarrolla vacuna contra Chikungunya. 2015 [consultado el 5 de julio de 2018]. Disponible en http://www.laprensa.hn/mundo/884347-410/m\%C3\%A9xico-desarrolla-vacuna-contra-chikungunya

81. Cadena Ser. España prueba con éxito en monos una vacuna contra el Chikungunya [Internet]. [Actualizado el 25 de agosto de 2015; consultado el 13 de octubre de 2017]. Disponible en http://cadenaser.com/ ser/2015/08/25/ciencia/1440520062_317454.html

82. El Mundo. Una vacuna contra el virus Zika estará lista para el final del verano [Internet]. [Actualizado el 04 de marzo de 2016; consultado el 14 de octubre de 2017. Disponible en http://www.elmundo.es/salud/2016/03/04/56d9d36f46163fe80f8b4644.html
83. INFOBAE. Estados Unidos anunció que trabaja en una vacuna contra el zika [Internet]. [Actualizado el 5 de agosto de 2017; consultado el 13 de octubre de 2017]. Disponible en http://www.infobae.com/america/eeuu/2016/08/04/estados-unidos-anuncio-que-trabaja-en-una-vacuna-contra-el-zika/

84. INFOSALUD. Los ensayos clínicos de la vacuna del Zika comenzarán a finales de 2016 [Internet]. [Consultado el 12 de octubre de 2017]. Disponible en http://www.infosalus.com/ salud-investigacion/noticia-ensayos-clinicos-vacuna-zika-comenzaran-finales-2016-20160129100053. html

85. Pan American Health Organization. Epidemiological alert: Neurological syndrome, congenital malformations, and Zika virus infection. Implications for public health in the Americas. Washington, DC: World Health Organization, Pan American Health Organization; 2015.

86. El País. La OMS respalda el uso de mosquitos transgénicos para combatir el zika [Internet]. [Actualizado el 16 de febrero de 2016; consultado el 10 de octubre de 2017]. Disponible en http://internacional.elpais.com/internacional/2016/02/16/actualidad/1455647360_674751.html

87. The Guardian. Millions of GM mosquitoes to fight Zika virus in Caymans [Internet]. [Actualizado el 6 mayo de 2016; consultado el 4 de octubre de 2017]. Disponible en https://www.theguardian.com/world/2016/ may/06/genetically-modified-mosquitos-zika-virus-cayman-islands

88. Korzeniewski K, Juszczak D, Zwolińska E. Zika - another Athreat on the epidemiological map of the world. International Maritime Health. 2016; 67(1):31-7. 